\title{
Diskursus Video Masker Ganda untuk Pencegahan COVID-19 di Channel Youtube CNN Indonesia
}

\author{
https://doi.org/10.25008/parahita.v2i1.56
}

\author{
Rachmaniar $^{1}$, Santi Susanti ${ }^{2}$ \\ ${ }^{1,2}$ Universitas Padjadjaran \\ Jl. Raya Bandung-Sumedang Km 21, Sumedang,45363 -Indonesia \\ * Email Korespondensi: rachmaniar@unpad.ac.id
}

\begin{abstract}
Abstrak
Tujuan penelitian ini adalah untuk menganalisis budaya virtual dari Video Masker Ganda untuk mencegah COVID-19 di Channel YouTube CNN Indonesia dilihat dari komentar netizen terkait dengan video tersebut. Metode yang digunakan adalah metode kualitatif melalui pendekatan etnografi virtual untuk menganalisis keberadaan Video Masker Ganda untuk Cegah COVID-19 di Channel YouTube CNN Indonesia. Objek penelitian ini adalah Video Masker Ganda untuk Cegah COVID-19 di Channel YouTube CNN Indonesia. Teknik pengumpulan data dilakukan melalui observasi partisipatif dan studi literatur. Hasil penelitian ini menunjukkan bahwa budaya virtual yang terbentuk atas komentar netizen terkait Video Masker Ganda untuk mencegah COVID-19 di Channel YouTube CNN Indonesia adalah: (1) netizen memprotes isi video; (2) netizen mengkritik tata cara penggunaan masker rangkap yang ada dalam video; (3) netizen menyetujui isi video; (4) netizen memberikan komentar lucu atas isi video; dan (5) tidak ada netizen yang memberi komentar apresiasi terkait video yang di-upload tersebut.
\end{abstract}

Kata kunci: budaya virtual, YouTube, masker ganda, etnografi virtual

\section{PENDAHULUAN}

Wabah coronavirus bermula di kota Wuhan, Cina pada Desember 2019. Bahaya potensial dari virus ini menjadi perhatian global ketika Dr. Li Wenliang dari sebuah rumah sakit di Wuhan berbagi pengetahuan yang dimilikinya dengan sesama dokter di WeChat terkait virus novel corona pada 30 Desember 2019.

Kota itu mulai melaporkan kematian pada 22 Januari. Dr. Li, yang pertama kali dituduh menyebarkan tipuan oleh polisi setempat, meninggal pada 7 Februari dalam usia 34 tahun. Ia kemudian dikonfirmasi telah terinfeksi dari seorang pasien virus corona yang berada di bawah pengawasannya. .

Pada tanggal 11 Maret 2020, WHO menyatakan sekitar 70 persen dari 7,8 miliar populasi di dunia rentan terinfeksi virus dan Indonesia menjadi salah satu negara yang rentan dengan virus tersebut. Hingga 15 Juli 2021, jumlah kasus positif COVID-19 di Indonesia terkonfirmasi bertambah 56.757 dari hari sebelumnya menjadi 2.726.803 kasus. Pada periode yang sama, jumlah kematian naik 982 menjadi 70.192, sedangkan pasien sembuh naik 19.049 menjadi 2.176.412. Padahal pemerintah Indonesia sudah menerapkan berbagai macam cara untuk mengurangi angka COVID-19 (Ekonid, 2021).

Salah satu hal yang dilakukan pemerintah adalah Program Vaksinasi COVID-19 mulai 13 Januari 2021. Ini dibagi menjadi empat fase dengan petugas kesehatan menerima vaksin gelombang pertama, diikuti oleh pegawai negeri dan anggota masyarakat lainnya. Pemerintah menargetkan menginokulasi total 181.554 .465 orang pada awal 2022. Pemerintah juga membuka vaksinasi COVID-19 untuk ibu hamil dan anak usia 12-18 tahun. Peluncuran dilakukan sehari setelah Badan Pengawas Obat dan Makanan Indonesia mengeluarkan izin penggunaan darurat untuk vaksin COVID-19 SinoVac yang dikembangkan China untuk wanita hamil dan anak-anak berusia antara 12 dan 18 tahun (Ekonid, 2021).

Hingga 15 Juli 2021, sebanyak 39.628.149 orang Indonesia menerima vaksinasi pertama, atau 718.716 lebih banyak dari hari sebelumnya. Sementara itu, 15.810.099 orang menerima vaksinasi kedua, atau 198.545 lebih banyak dari hari sebelumnya. Sementara itu, 
per 15 Juli 2021, untuk DKI Jakarta, sebanyak 6.069.993 orang mendapatkan vaksinasi pertama, sementara 1.970.308 orang mendapatkan vaksinasi kedua (Ekonid, 2021).

Selain vaksin, hal yang juga dilakukan pemerintah adalah membatasi mobilitas masyarakat dengan mewajibkan setiap orang yang melakukan perjalanan dalam kawasan aglomerasi untuk memiliki surat persetujuan yang menyatakan mereka adalah bagian dari sektor usaha yang dikategorikan sebagai sektor esensial atau kritis sebagaimana ditetapkan oleh implementasi kebijakan PPKM Darurat.

Sektor usaha yang diizinkan beroperasi pada kapasitas 50\% di bawah kategori esensial dan kapasitas $100 \%$ di bawah kategori kritis. Ini termasuk, misalnya, layanan keuangan yang berorientasi pada interaksi fisik dengan pelanggan, sementara staf administrasi hanya diperbolehkan bekerja dari kantor dengan kapasitas 25\%, di antara klarifikasi lainnya.

Lalu juga semua warga negara asing yang masuk ke Indonesia wajib menunjukkan sertifikat yang menunjukkan mereka telah divaksinasi. Selain itu, pelancong harus mematuhi masa karantina $8 \times 24$ jam di zona karantina bersertifikat pemerintah. Persyaratan ini dikecualikan bagi warga negara asing dengan visa diplomatik, yang bepergian dalam kapasitas sebagai perwakilan pemerintah mereka, atau memasuki Indonesia melalui skema Pengaturan Koridor Perjalanan.

Semua pelancong internasional yang memenuhi syarat untuk memasuki Indonesia sebagaimana ditetapkan oleh Direktorat Jenderal Imigrasi Indonesia wajib mematuhi karantina 8 hari dan penyelenggaraan kembali Tes RT-PCR. Hanya WNI yang bepergian dari luar negeri yang biaya karantina dan tes RT-PCR-nya ditanggung pemerintah. Selanjutnya, wisatawan internasional yang masuk ke Indonesia juga harus menunjukkan kartu vaksinasi yang menyatakan wisatawan tersebut telah divaksinasi lengkap. Amandemen tersebut berlaku efektif mulai 6 Juli 2021.

Mulai 3 Juli hingga 20 Juli, pemerintah daerah melakukan pembatasan yang lebih ketat pada aktivitas publik. Semua sektor bisnis yang tidak penting wajib menerapkan kebijakan WFH $100 \%$, mal dan pusat perbelanjaan tutup, sementara restoran hanya dapat melayani delivery atau take away, dan semua rumah ibadah tutup. Sektor-sektor penting dan kritis tertentu seperti sektor kesehatan dan telekomunikasi akan tetap beroperasi dalam kapasitas tertentu sementara supermarket dan toko mandiri yang menjual kebutuhan pokok sehari-hari dapat buka hingga jam 8 malam dan hanya dengan protokol kesehatan yang ketat.

Hal ini dilakukan pemerintah menyusul munculnya kembali COVID-19 yang terjadi karena meningkatnya mobilitas orang selama dan pasca musim libur nasional awal Mei lalu. Tercatat terjadi peningkatan 5,2\% jumlah kasus COVID-19 per 23 Mei 2021. Disamping itu juga karena merebaknya virus corona varian Delta di Indonesia (Ekonid, 2021).

Varian Delta adalah varian yang menyebabkan gejala yang lebih parah dan lebih mudah menular. Orang yang terkena varian Delta, 2.61 lebih berisiko untuk dirawat di rumah sakit daripada yang terkena varian Alpha. Hal ini sangat meresahkan mereka yang belum divaksinasi penuh atau sama sekali belum divaksinasi, serta mereka yang mempunyai respons kekebalan lemah terhadap virus (Mohay, 2021).

Adapun gejala orang yang terkena varian Delta adalah tingkat virus dalam tubuh meningkat lebih tinggi dari sebelumnya. Lalu akan merasakan sakit parah selama tiga sampai empat hari (Mohay, 2021). Biasanya mereka sakit perut, hilang selera makan, muntah, mual, nyeri sendi, gangguan pendengaran, sakit kepala, sakit tenggorokan, pilek dan demam (Widayanti, 2021). Ini yang menyebabkan lonjakan kasus COVID-19 seperti terjadi Inggris dan India yang meningkat tajam.

Untuk itu himbauan-himbauan kepada masyarakat terus dilakukan pemerintah guna mengurangi risiko terkena varian Delta. Salah satu himbauan yang kerap disampaikan pemerintah adalah penggunaan masker ganda. Penggunaan masker ganda dilakukan dengan memakai masker medis dan menutupinya dengan masker kain. Dengan penggunaan dua masker secara bersamaan akan membuat seseorang mendapat perlindungan optimal $85 \%$ dari Coronavirus (Sofa, 2021). 
Hal serupa juga disampaikan Ketua Bidang Perubahan Perilaku Satgas Penanganan COVID-19, Sonny Harmadi, yang menyarankan masyarakat menggunakan masker ganda guna mencegah penularan COVID-19. Menurutnya, masker kain memiliki kerapatan yang lebih baik tetapi filtrasi lebih rendah dibandingkan dengan masker medis. Sementara masker medis, filtrasi lebih bagus tetapi kerapatan lebih rendah.

Atas hal tersebut, tidak mengherankan jika banyak channel YouTube yang menghimbau masyarakat terkait penggunaan masker ganda, salah satunya Channel YouTube milik CNN Indonesia. Dalam video berjudul Masker Ganda untuk Cegah COVID-19, dengan durasi 3:33 menit, produser lapangan Puti Fanfudi, menginformasikan alasan masyarakat harus menggunakan masker ganda, serta petunjuk teknis - tata cara menggunakan masker ganda.

Video yang pertama kali dipublikasikan pada tanggal 25 Juni 2021 ini, hingga 20 Juli 2021 itu telah ditonton 17 ribu kali, dan mengundang 110 netizen untuk memberikan komentar. Hal ini tentu menarik untuk dikaji, guna mengetahui seperti apa respon netizen atas penggunaan masker ganda ini, yang selanjutnya bisa membawa penulis mengetahui bagaimana budaya virtual yang terbentuk atas video yang diupload tersebut - kategorisasi atau pola tertentu terkait komentar-komentar yang disampaikan netizen. Guna menjawab pertanyaan penelitian ini, penulis menggunakan pendekatan kualitatif dengan metode etnografi virtual.

\section{KERANGKA TEORI}

Penelitian ini menggunakan teori mediated communication sebagai sautu bentuk komunikasi dalam menyampaikan pesan dari komunikator kepada komunikan dengan menggunakan sarana peralatan komunikasi dalam bentuk computer mediated communication (CMC) yakni komunikasi manusia yang brlangsung melalui penggunaan perangkat komunikasi (McQuail, 2005).

Bentuk CMC saat ini yang paling banyak digunakan oleh komunikator maupun komunikan adalah media massa dan media sosial dalam berbagai bentuk platformn. Media sosial dengan jaringan internet yang luas, menjangkau khalayak secara cepat dan mudah serta murah, membuat pesan dengan cepat bisa mencapai sasaran khalayak.

Oleh sebab itu internet saat ini juga menjadi bagian dari CMC. "Internet sebagai sebuah bentuk computer mediated communication, memiliki pengertian proses komunikasi yang dilakukan menggunakan komputer, melibatkan manusia, terjadi pada konteks tertentu dengan melibatkan proses pembentukkan media untuk berbagai tujuan” (Astuti, 2011).

Komunikasi dengan menggunakan internet dapat dikatagorikan sebagai bentuk komunikasi massa yang dapat membentuk komunikasi personal dalam jumlah banyak. Pengguna internet dalam melakukan komunikasi dengan pengguna lain dalam fungsi sebagai komunikator dan komunikan untuk saling bertukar pesan (Effendi, 2010).

\section{METODE PENELITIAN}

Studi ini menggunakan pendekatan kualitatif. Penelitian kualitatif menawarkan pendekatan sistematis untuk mempelajari fenomena dalam konteks tertentu (Gast, 2010). Ini adalah eksplorasi dan upaya untuk mengembangkan penjelasan (Lincoln \& Guba, 1985). Fenomena diperiksa secara luas dan mendalam yang berguna ketika masalah berada pada tahap awal (Babbie, 1989). Data dihasilkan dari wawancara, observasi langsung, analisis artefak, dokumen, catatan budaya, bahan visual atau pengalaman pribadi (Denzin \& Lincoln, 1994).

Berg dan Howard (2012) mencirikan penelitian kualitatif sebagai makna, konsep, definisi, metafora, simbol dan deskripsi hal-hal tertentu. Karenanya, pendekatan penelitian kualitatif menyediakan data berlimpah tentang orang-orang dan situasi kehidupan nyata (De Vaus, 2014, p6; Leedy dan Ormrod, 2014).

Ketergantungan pada pengumpulan data primer non-numerik seperti kata-kata dan gambar oleh peneliti yang berfungsi sebagai instrumen sendiri membuat penelitian kualitatif cocok untuk memberikan fakta dan informasi deskriptif(Johnson dan Christensen, 2012, p29- 
37). Bogdan dan Biklen (1982) menyatakan bahwa penelitian kualitatif adalah deskriptif yang datanya dikumpulkan dalam bentuk kata atau gambar daripada angka.

Sementara itu etnografi virtual adalah metode etnografi yang dilakukan untuk melihat fenomena sosial dan kultur pengguna di ruang siber (Nasrullah, 2014). Etnografi virtual mempertanyakan asumsi yang berlaku secara umum tentang internet, menginterpretasikan sekaligus reinterpretasi internet sebagai sebuah cara sekaligus medium untuk berkomunikasi, merupakan ethnography in, of and trough the virtual - interaksi tatap muka atau face to face tidak diperlukan (Hine, 2001).

Tom Boellstorff, professor di bidang antropologi University of California, menyatakan penelitian etnografi virtual, pada dasarnya memiliki prinsip-prinsip yang sama dengan penelitian etnografi, dimana proses melakukan dan membangun etnografi menggunakan lingkungan virtual online sebagai lokasi penelitian.

Boellstorf menyatakan pengumpulan data penelitian di luar lokasi (dunia virtual) penelitian sama saja dengan melanggar prinsip in their own term, karena bagaimanapun juga segala sesuatu memiliki makna dalam konteksnya sendiri.

Dalam etnografi virtual, wawancara dan survei dapat digantikan oleh koleksi/arsip yang sudah ada yang berasal dari informasi yang melimpah di lingkungan online seperti situs jejaring sosial dan forum internet. Informasi dapat ditemukan dan diarsipkan dari internet tanpa harus dicatat dan ditulis seperti etnografer tradisional (Evans, 2010:2).

\section{HASIL PENELITIAN}

Berdasarkan keberadaan Video Masker Ganda untuk Cegah COVID-19 di Channel YouTube CNN Indonesia, diketahui netizen memiliki beberapa kategorisasi atau pola, atau budaya virtual, yaitu memprotes isi video, mengkritik tata cara penggunaan masker rangkap yang ada di video, menyetujui isi video, dan memberikan komentar lucu atas isi video.

Tidak ada netizen yang memberikan apresiasi terhadap isi video yang di-upload pada Channel YouTube tersebut. Begitu juga dengan yang memberikan pertanyaan, jumlahnya sangatlah sedikit, tidak sebanding dengan jumlah netizen yang memprotes atau mengkritik isi video tersebut.

\section{Protes terhadap Isi Video}

Menurut Kamus Besar Bahasa Indonesia, protes berarti pernyataan tidak menyetujui, menentang, menyangkal, dan sebagainya. Dalam Video Masker Ganda untuk Cegah COVID19 di Channel YouTube CNN Indonesia, banyak netizen memprotes isi video. Protes terbanyak menyebut, mereka sesak nafas jika menggunakan masker ganda. Penggunaan satu masker saja sudah membuat mereka sesak, terlebih jika harus menggunakan dua. Lalu juga hingga saat ini netizen merasa penggunaan satu masker dengan cara yang benar saja belum dilakukan setiap orang. Masih banyak orang menggunakan masker dengan cara yang tidak benar: masker tidak menutupi hidung, tetapi hanya menutupi mulut atau dagu.

Selain itu juga banyak orang yang belum memiliki kesadaran menggunakan satu masker, dan sekarang ada himbauan untuk menggunakan dua masker. Hal ini tentu menjadi sesuatu yang sulit dilakukan.

Netizen juga berkomentar himbauan yang disampaikan tidak cukup bernalar. Netizen menyampaikan, sebenarnya virus itu bisa masuk melalui tangan. Sehingga pemakaian masker ganda bukanlah satu-satunya cara terhindar dari virus. Ditambah juga saat menggunakan masker, terlebih masker ganda, tentu gas yang dihirup adalah gas hasil pembuangan oksigen, yaitu karbondioksida yang tidak keluar ke udara saat dihembuskan karena tertutup masker. Lalu karbondioksida dihirup dan itu membuat orang lemas dan sesak nafas. Ini berbahaya. Sehingga atas hal tersebut, ada netizen yang menyatakan bahwa maskermu, membunuhmu.

Protes lain yang disampaikan netizen adalah keberadaan orang gila yang berkeliaran tanpa masker, dan mereka tampak baik-baik saja, tidak lemas atau pusing seperti orang-orang yang menggunakan masker. Sekarang ada himbauan penggunaan masker ganda, tentu hal ini 
dianggap sebagai omong kosong - hal yang sia-sia untuk disampaikan. Penggunaan masker rangkap dianggap sebagai pemborosan, yang berujung pada keuntungan bagi penjual masker.

Atas protes yang disampaikan tersebut, netizen beranggapan bahwa sekalian saja masyarakat dihimbau menggunakan masker lebih dari dua, menggunakan helm, dan juga membawa tabung oksigen untuk terhindar dari sesak nafas dan juga COVID-19.

\section{Kritik terhadap Tata Cara Penggunaan Masker Rangkap}

Kritik dalam Kamus Besar Bahasa Indonesia berarti kecaman atau tanggapan, kadangkadang disertai uraian dan pertimbangan baik buruk terhadap suatu hasil karya, pendapat, dan sebagainya. Kritik menarik yang disampaikan netizen dalam Video Masker Ganda untuk Cegah COVID-19 di Channel YouTube CNN Indonesia adalah kritik terkait tata cara penggunaan masker rangkap. Ada dua kritik keras yang disampaikan netizen dalam video ini.

Kritik pertama, masker yang dijadikan contoh oleh produser lapangan, Puti Fanfudi. Di awal, dalam narasi video disebutkan masker yang digunakan dalam masker ganda, terdiri dari masker kain dan masker medis. Puti Fanfudi dalam video pun beberapa kali menyebut masker kain dan masker medis. Tetapi saat mempraktekkan penggunaan masker rangkap, masker yang digunakan Puti Fuadi adalah masker medis dan masker scuba. Sontak saja hal ini menuai kritik dari netizen karena yang disampaikan tidak sesuai dengan yang dicontohkan. Netizen berpendapat bahwa masker scuba berbeda dengan masker kain.

Hal kedua yang banyak dikritik oleh netizen adalah himbauan Puti Fanfudi terkait tidak diperkenankan memegang bagian luar dan dalam masker medis. Pada saat memegang masker medis, sebaiknya bagian yang dipegang adalah talinya. Pada saat mempraktekkan penggunaan masker medis, ternyata Puti Fanfudi justru memegang bagian luar dan dalam dari masker. Hal ini menuai kritikan keras dari netizen. Lagi-lagi hal yang disampaikan, tidak sesuai dengan yang dipraktekkan. Ini membuat netizen menyatakan CNN Indonesia dianggap kurang cerdas.

\section{Menyetujui Isi Video}

Selain menuai protes dan kritik dari netizen, video berdurasi 3:33 menit itu disetujui oleh beberapa netizen. Ada beberapa netizen yang sependapat dengan pemakaian masker rangkap. Netizen ada yang menyatakan dirinya kerap menggunakan masker rangkap, dengan dua masker medis yang digunakan. Tentu hal ini jauh lebih berat daripada menggunakan satu masker medis dan satu masker kain.

Selain itu juga ada netizen yang menyatakan kerap menggunakan masker tiga lapis - dua masker medis dan satu masker kain. Atas hal tersebut, himbauan menggunakan masker rangkap bukanlah hal yang sulit untuk dirinya.

Lalu juga ada netizen yang menyatakan bahwa sebelum pandemi, netizen ini telah membiasakan diri menggunakan masker. Netizen ini mengikuti kebiasaan orang-orang Korea dan Jepang.

Terakhir, netizen yang menyetujui isi video menyatakan bahwa penggunaan masker ragkap nyatanya tetap membuat mereka bisa bernafas, dan tidak sesak seperti yang diprotes banyak netizen sebelumnya.

\section{Memberikan Komentar Lucu}

Terkait komentar lucu, ada yang menyatakan penggunaan masker bengkuang dan komedo tentu lebih menyenangkan daripada penggunaan masker rangkap. Di sini netizen tidak memprotes atau mengkritik isi video, tetapi juga tidak menyetujui. Netizen hanya mengungkapkan sesuatu yang lucu dan menghibur dibalik penggunaan masker rangkap.

Hal lucu lain yang juga disampaikan netizen adalah keberadaan masker yang selalu viral di setiap tahunnya selama pandemi seperti sekarang ini. Dan ini juga memunculkan istilah baru yaitu poligami masker. Kembali netizen tidak memprotes atau mengkritik isi video. 
Terdapat 110 komentar di kolom komentar, dan tidak ada satu pun netizen yang menyatakan apresiasinya terhadap video tersebut. Tidak ada netizen yang menyatakan video ini memberi manfaat, memberi edukasi, ataupun memberikan masukan serta pengetahuan terkait penggunaan masker yang baik dan benar dalam situasi pandemi seperti sekarang ini. Focus netizen banyak tercurah kepada hal lain di luar itu. Penggunaan masker yang membuat sesak nafas, ataupun hal-hal yang disampaikan dalam video tidak sesuai dengan yang dipraktekkan. Dan ini tentu harus menjadi perhatian lebih dari pemilik channel YouTube untuk membuat konten sedetail mungkin, menyelaraskan antara pernyataan dan tindakan.

Temuan dalam penelitian ini adalah, Channel YouTube CNN Indonesia belum berhasil membuat netizen memberikan banyak pernyataan positif atau pernyataan yang mengapresiasi terkait video. Justru dalam video ini, banyak netizen yang memberikan komentar negatif, seperti memprotes dan mengkritik video yang di-upload. Kecenderungan komentar netizen tidak menyukai video tersebut.

Ke depan, Channel YouTube CNN Indonesia harus secara detail memperhatikan narasi, script, serta gambar yang akan di-upload. Jika ada hal yang tidak sesuai, hal ini akan membuat netizen fokus pada kesalahan yang hadir dalam video tersebut, sehingga manfaat dari video tidak dirasakan lagi oleh netizen.

Lalu diketahui juga, sebenarnya masih ada netizen yang menyetujui isi video. Hanya disayangkan pada saat netizen memberikan protes atau kritik, tidak ada pihak yang memberikan penjelasan atau pendapat guna meluruskan kesimpangsiuran yang terjadi. Sebaiknya ada pihak-pihak, atau ahli dan pemilik channel youtube yang bisa mengedukasi pemikiran netizen yang kurang tepat. Sehingga protes dan kritik tidak hadir, tetapi eduaksi dan apresiasi yang banyak muncul pada kolom komentar.

\section{KESIMPULAN}

Berdasarkan keberadaan Video Masker Ganda untuk Cegah COVID-19 di Channel YouTube CNN Indonesia, netizen memiliki lima budaya virtual, yaitu memprotes isi video, mengkritik tata cara penggunaan masker rangkap yang ada dalam video, menyetujui isi video, memberikan komentar lucu atas isi video, dan tidak ada komentar apresiasi terkait video yang di-upload

Banyak netizen yang memprotes isi video, dengan komentar yang paling banyak muncul adalah rasa sesak nafas ketika menggunakan masker

Channel YouTube CNN Indonesia harus secara detail memperhatikan narasi, script, serta gambar yang akan di-upload, agar pernyataan dan tindakan dalam video selaras

\section{Daftar Pustaka}

Babbie, E. (1989). The Practice of Social Research, 5th edition. Belmont CA: Wadsworth.

Berg, B. L. \& Howard, L. (2012). Qualitative Research Methods for the Social Sciences. (8th ed). USA: Pearson Educational Inc.

Boellstorff, T. (2008). Coming of Age in Second Life : An Anthropologist Explores the Virtually Human. New Jersey: Princenton University Press.

De Vaus, D. A. (2014). Surveys in Social Research. (6th ed). Australia: UCL Press

Denzin, N.K. \& Lincoln, Y.S. (1994). Handbook of Qualitative Research. Thousand Oaks: Sage.

Ekonind. (2021). COVID-19 Developments in Indonesia. Diakses pada 20 Juli 2021 dari https://indonesien.ahk.de/infothek/news/news-details/covid-19-developments-inindonesia

Gast, D. L. (2010). Single Subject Research Methodology in Behavioral Sciences. New York: Routledge.

Hine, C. (2001). Virtual Ethnography. London: Sage Publication Ltd.

Johnson, B. \& Christensen, L. (2012). Educational Research, Qualitative, Quantitative and Mixed Approach. (4th ed). California: SAGE Publication. 
Leedy, P. \& Ormrod, J. E. (2014). Practical Research Planning and Design. (10th ed). Edinburgh: Pearson Educational Inc.

Lincoln, Y. S. \& Guba, E. G. (1985). Naturalistic Iinquiry. Beverly Hills, CA: Sage

Mohay, F. 2021. Penjelasan Terkait Varian Delta dan Perbedaannya dengan Virus Corona yang Menyebar di Wuhan. Diakses pada 20 Juli 2021 dari https://www.tribunnews.com/kesehatan/2021/07/04/penjelasan-terkait-varian-deltadan-perbedaannya-dengan-virus-corona-yang-menyebar-di-wuhan?

Nasrullah, R. (2014). Teori dan Riset Media Siber (Cybermedia). Jakarta:Kencana

Sofa, A. (2021). Things You Need To Know About Covid-19 Delta Variant. Diakses pada 20 Juli 2021 dari https://corona.jakarta.go.id/en/artikel/covid-19-varian-delta-dan-hal-halyang-harus-kamu-perhatikan

Widayanti, O.W. (2021). Apa Itu Varian Delta? Apa Gejalanya Sama dengan Virus Corona Pada Umumnya? Berikut Penjelasannya. Diakses pada 20 Juli 2021 dari https://www.tribunnews.com/nasional/2021/06/22/apa-itu-varian-delta-apa-gejalanyasama-dengan-virus-corona-pada-umumnya-berikut-penjelasannya? 